\title{
Prostate Ductal Adenocarcinoma
}

National Cancer Institute

\section{Source}

National Cancer Institute. Prostate Ductal Adenocarcinoma. NCI Thesaurus. Code C6813.

A usually aggressive invasive adenocarcinoma of the prostate gland composed of large glands containing tall columnar cells. The columnar cells have abundant cytoplasm and are reminiscent of endometrial carcinoma. This type of adenocarcinoma has a tendency to metastasize to the lung and penis. 